\title{
The impact of FTAs on MENA trade in agricultural and industrial products
}

M.D. Parra a, *, I. Martinez-Zarzoso ${ }^{\text {b }}$ and C. Suárez-Burguet c

\begin{abstract}
${ }^{a}$ Research Group of Industry and Territory. Department of Economics- CREIP, Universitat Rovira i Virgili, Av. Universitat 1; 43204-Reus, Spain and Instituto de Economía Internacional, Universitat Jaume I, , Campus del Riu Sec, Castellón, 12071, Spain.Phone: (+34)977759848.E-mail:maria.parra@urv.cat

${ }^{b}$ Instituto de Economía Internacional and Department of Economics, Universidad Jaume I, Campus del Riu Sec, 12071 Castellón, Spain and Ibero American Institute for Economic Research, Goettingen, Germany. Phone: (+49) 551399770 Email:martinei@eco.uji.es

'Instituto de Economia Internacional and Department of Economics, Universidad Jaume I, Campus del Riu Sec, 12071 Castellón, Spain.Phone: (+34)964 387159.E-mail: celes@eco.uji.es
\end{abstract}

This paper analyses the impact of Free Trade Agreements (FTAs) on Middle East and North African Countries (MENA) trade for the period 1994-2010. The analysis distinguishes between industrial and agricultural trade to take into account the different liberalisation schedules. An augmented gravity model is estimated using up-to-date panel data techniques to control for all time-invariant bilateral factors that influence bilateral trade as well as for the so-called multilateral resistance factors. We also control for the endogeneity of the agreements and test for self-selection bias due to the presence of zero trade in our sample. The main findings indicate that North-South-FTAs and South-SouthFTAs have a differential impact in terms of increasing trade in MENA countries, with the former being more beneficial in terms of exports for MENA countries, but both showing greater global market integration. We also find that FTAs that include agricultural products, in which MENA countries have a clear comparative advantage, have more favourable effects for these countries than those only including industrial products.

JEL code: F10, F15

*Corresponding author. E-mail: maria.parra@urv.cat 


\section{Introduction}

The reduction in the number of trade barriers through the implementation of trade agreements is a major step towards trade liberalization. The MENA (Middle East and North African) countries have greatly increased their participation in FTAs (Free Trade Agreements) in the last ten years, both in North-South FTAs and South-South FTAs. But have they really helped to improve trade integration in the region? Ad-valorem tariffs in MENA countries have been reduced in the last 15 years by about 5 percentage points and the openness ratio has risen from $47 \%$ in 2000 to 66 in $2008 .{ }^{1}$ Exchanges with the European Union (EU) represent more than $60 \%$ of total trade for some MENA countries, but have been losing ground in the last years in favour of new emerging partners.

A number of articles have recently analysed the impact of FTAs on MENA trade flows. Most of the studies cover only the late 1990s and early 2000s (Peridy, 2005a, 2005 b; Cieslik and Hagemejer, 2009) and only two compare different FTAs, including NorthSouth FTAs and South-South FTAs (Abedini and Peridy, 2008; Cieslik and Hagemejer, 2009). As far as we are aware, there is a lack of studies that specifically differentiate between the effect of the agreements on trade in industrial and agricultural products. The present study adds new insight along these lines. The main aim of this paper is therefore to analyse the impact on trade in agricultural and industrial products of the FTAs which came into force for ten MENA countries during the period from 1994 to 2010. We focus in particular on the effects of recent FTAs that include trade liberalization in agricultural goods and compare the average impact of the agreements on trade, differentiating between import and export flows. To this end, an augmented gravity model is estimated using upto-date panel data techniques that allow to control for all bilateral factors that influence bilateral trade and are time-invariant (unobserved heterogeneity), as well as for the so-called multilateral resistance factors (the effect of relative prices with respect to all trading partners). We use the methodology recently proposed by Baier and Bergstrand (2007) to control for the endogeneity of the agreements and for multilateral resistance factors.

The main results show that the majority of the FTAs considered increase bilateral trade between the countries involved in the agreement, except for the Euromed agreement, which only increases MENA imports from the EU, but not exports to the EU. We also found that the inclusion of agricultural liberalization in the agreements could mitigate MENA concessions on industrial import liberalization.

${ }^{1}$ FEMISE (2011). 
The rest of the paper is organized as follows. Section II describes the FTAs analysed in the paper and revises the related literature. Section III presents the analytical framework. Section IV describes the data and specifies the empirical model. Section V presents the main results and Section VI concludes.

\section{Free Trade Agreements in the MENA region}

\section{Overview of the integration processes}

In this sub-section we briefly describe the FTAs recently signed by MENA countries distinguishing between North-South and South-south agreements. As regards North-South FTAs, MENA countries have signed agreements with the EU, EFTA and US. The main trading partner for MENA countries, especially for North African Countries, has been and is the EU. This has been partly due to the geographical proximity and the historicalcolonial ties between both areas. The integration process between the South Mediterranean counties (SMC) and the EU started in 1969 with the Preferential Trade Agreements (PTAs) that liberalized industrial exports from Algeria, Morocco and Tunisia to EU countries. Within the framework of the 'Global Mediterranean Policy', which started in 1972, bilateral cooperation agreements between the EU and Morocco, Israel, Tunisia, Egypt, Jordan, Lebanon and Syria were signed in 1975. These agreements included non-reciprocal trade preferences liberalizing industrial exports from some MENA countries to Europe.

With the aim of re-launching Euro-Mediterranean integration, the Barcelona Process started in 1995. One of its main goals was to complete a Free Trade Area between the European Union (EU) and each MENA partner involved in the process by $2010^{2}$. The main vehicle to reach full liberalisation has been the negotiation and enforcement of interim bilateral agreements between each South Mediterranean country and the EU. Within this framework, single interim bilateral agreements have already entered into force for seven countries (see Table A.1 in Appendix).

In addition to the Euromed Agreement, some MENA countries signed separated FTAs with members of the European Free Trade Association (EFTA). The FTAs came into force with Turkey in 1992, Israel in 1993, Morocco in 1999, Jordan in 2002, Tunisia in 2005, Lebanon and Egypt in 2007. The coverage of the agreements is similar to the coverage of the Euromed Agreement and includes trade in industrial products, as well as

\footnotetext{
${ }^{2}$ See Montanari (2007) and Femise (2009, for more details about the regional integration process the in EuroMediterranean area.
} 
trade in fish and other marine products and processed agriculture and also provisions related to the elimination of other trade barriers.

An additional North-South FTA is that signed by Jordan and the USA ${ }^{3}$, which came into force in 2001 with the aim of promoting product and service exports between both countries. Each party shall progressively eliminate its customs duties over a period of ten years. Before this agreement, the two countries had signed an agreement for the creation of Qualifying Industrial Zones (QIZ) in 1998, which allowed products to enter the USA duty free if $35 \%$ of the appraised value was from Israel, Jordan, Egypt, or the West Bank and Gaza. A similar FTA was signed by the USA and Morocco ${ }^{4}$, which came into force in 2006 and has a transition period of 18 years for the USA and 25 years for Morocco. The FTA includes trade liberalization for goods and services. The agreement was signed after the end of the Multi-Fiber Agreement (MFA) on the 1st of January 2005 and was seen by Morocco as an opportunity to diversify its economy.

Another North-South FTA came into force in 1997 between Israel and Canada. The agreement eliminates tariffs on all industrial products manufactured in both countries and also on a limited number of agricultural and fisheries products.

Moving to the South-South FTAs, Turkey has signed a number of FTAs with MENA countries. The content of the agreements is also quite similar to the content of the Euromed framework, though with minor differences, one being that each country has different transition periods to complete full liberalisation. ${ }^{5}$ This shift in foreign policy in Turkey shows the new role that Turkey aims to play in Mediterranean relations, starting with ambitious trade integration plans in the region (Balcer, 2013).

Apart from the bilateral agreements with Turkey, other varieties of South-South integration attempts have failed and efforts on behalf of the MENA countries have not been sufficient to develop successful arrangements ${ }^{6}$. In particular, Arab regional integration began in the 1950s after the creation of the Arab Common Market and under a number of treaties, conventions and councils, which had no impact and were unable to increase intra-regional trade. For this reason, a new attempt was made in 1964 with the signing of "The Arab Common Market Agreement", which sought to create a free trade area through the establishment of a common external tariff. Once again, this initiative failed to pave the way

${ }^{3}$ See Ruebner (2000), Rosen (2004), Nugent and Abdel-Latif (2010) and Awad (2011), for more detail of the FTA and QIZ between Jordan and US.

${ }^{4}$ See Hufbauer and Brunel (2009) chapter 8, and Abdelmalki (2011) for more detail of the FTA between Morocco and US.

${ }^{5}$ See Table A.1 in the Appendix for more details about the liberalisation process of each agreement.

6 See Romagnoli, and Mengoni (2009) and FEMISE (2005; 2006; 2008; 2009) for a historical review of the MENA integration. 
to further integration in the region, Broude (2009). Other attempts were "The Gulf Cooperation Council (GCC) "in 1981 and "The Arab Maghreb Union". It was only in the 1990s, when Arab countries entered a new phase of South-South integration highlighting two relevant agreements, the Great Arab Free Trade Area (GAFTA) and the Agadir Agreement.

The GAFTA agreement was signed in 1997 by 14 Arab countries in order to create a free trade area among its members, with a gradual 10\% annual reduction in tariffs and taxes between 1998 and 2007, so they will be totally eliminated in ten years. But with the aim of accelerating integration in the region, the Social Council of the Arab League announced full liberalisation by 2005 . $^{7}$

Within this context of Pan-Arab integration, Egypt, Jordan, Morocco and Tunisia signed the Agadir agreement in Rabat in 2004 to promote trade integration parallel to other projects. ${ }^{8}$ The Agadir agreement entered into force in 2006. The agreement establishes a free trade area and adopts the Pan-Euro-Med Rules of Origin, which allow the use of standardized inputs for the production of final goods from any country in the EU, EFTA or the signatories of the Agadir agreement itself to benefit from the exemption of tariffs with the EU. The agreement aims at providing full liberalisation of trade in industrial goods and agricultural products.

In addition, Israel concluded an FTA with Mexico that came into force in 2000 for industrial and some agricultural products. Both parties agreed to eliminate customs duties for a list of products and, at the beginning of the following year, for the rest of products, completing full liberalisation in 2005. Finally, Jordan signed an FTA with Singapore in 2004, including industrial and agricultural goods. The agreement eliminates tariffs for imports from Jordan to Singapore since 2005, while tariffs for imports from Singapore are progressively reduced over a timeframe of 5 to 10 years.

\section{Impact on trade of MENA integration processes}

After describing the main integration processes in which MENA countries are involved, the central question that emerges is to what extent these processes have been successful in promoting trade and economic integration. While most of the research published focuses on other regions like the European Union, North America, Latin America and more recently Asia, relatively few studies have turned their attention to the impact of FTAs on MENA trade flows.

${ }^{7}$ See Zarrouk (2000) and Zorob (2008) for more details about the GAFTA agreement.

${ }^{8}$ See Wippel (2005) and Abedini and Peridy (2008) for more detail about the Agadir agreement. 
Kepaptsoglou et al. (2010) review empirical studies in the last 10 years that use gravity model specifications to analyse the impact of FTAs on international trade flows. In the literature that examines trade integration effects on MENA trade flows using gravity models, some studies exclusively focus on North-South integration, namely Peridy (2005a), Ruiz and Villarubia (2007), Bergstrand et al. (2011) and Montalbano and Nenci (2012), some ohers include also South-South integration agreements (Peridi, 2005b; Abedini and Peridy, 2008; Cieslik and Hagemejer, 2009). Overall, most of them only cover the late 1990s and early 2000s and analyse the impact of FTAs on exports alone using total values, not taking into account the nature of the agreements.

Peridy (2005a) analyses the impact of regional arrangements between the EU and seven Mediterranean countries for the period 1975-2001. He employs a gravity equation and uses different model estimators (Fixed effects, Random Effects, Hausman-Taylor and a dynamic estimation with GMM). His main findings indicate that the regional agreement between the EU and MENA countries has a positive and significant impact on exports from MENA countries to the European Union in all estimations, with trade creation estimated at around 20\%-27\% for the static specifications and 36\% in the dynamic version. Peridy (2005b) focuses on the effects of the Agadir agreement, analysing the impact of the regional trade agreement between 5 MENA countries and between those and the EU from 1975 to 2001. His results show that despite the fact that the Agadir Agreement reduced trade barriers, the high border effects and lack of complementarities meant that the countries involved in the Agadir agreement obtained a limited benefit in terms of higher trade flows. Abedini and Peridy (2008) measured the impact that the GAFTA agreement has had on exports of 15 member countries from 1988 to 2005, obtaining a positive and significant correlation in all estimates. They estimated a trade creation effect of around 1624\%. Their study also evaluated the impact of the Association Agreements (AAs) with the European Union and the new Euromed agreement, obtaining a positive and significant effect for the AAs with the EU and a negative effect for the Euromed agreement. Cieslik and Hagemejer (2009) also analyse both North-South and South-South FTAs using an augmented gravity model to estimate FTA effects on imports and exports for seven MENA countries between 1980-2004. Similar to Peridy (2005a), they include county pairspecific effects and time-specific effects and present different specifications to check for robustness, including OLS, two-way fixed effects and first differences. According to their findings, the EU-Association Agreement with MENA countries has a positive and significant effect on MENA imports from the EU, but does not help to increase MENA 
exports to the EU. In the case of FTAs with the US, they find a positive and significant effect on imports and exports, whereas the parameter estimates for Arab FTAs are mostly not statistically significant. Individual effects for each MENA country are also estimated, showing mixed results. Bergstrand et al. (2011) study the impact of six trade agreements for the European Union, including the FTA between the EU and Jordan, Morocco and Tunisia. They used a gravity model for bilateral trade flows among 176 pairs of countries for the period 1966-2008. Their results show that the FTAs have only improved exports from the EU to Tunisia and Morocco, but not in the opposite direction.

Our analysis is closely related to Cieslik and Hagemejer (2009) but with three important improvements. First, we include more recent years in the analysis and consider new FTAs which have come into force until 2010, excluding the years after the Arab spring revolution, initiated in 2011. Second, we differentiate between trade in industrial and agricultural products and estimate the effect of the agreements separately, which is reasonable given the remarkable differences in terms of trade liberalisation for these two types of products. Finally, we control for both the endogeneity of the trade agreement variable and multilateral resistance terms, as suggested by Baier and Bergstrand (2007). Previous studies fail to control for multilateral resistance that is time variant.

\section{III.Analytical framework}

The gravity model of trade, which is one of the most well accepted models used to explain bilateral trade flows (Anderson and Wincoop, 2003; Baier and Bergstrand, 2007), has been selected as the analytical framework in this paper. As reported in the previous section, it has been extensively used to estimate the impact of trade policy actions on bilateral trade flows.

The basic model states that trade between two countries $(\mathrm{T})$ is proportional to the product of their economies, which can be measured using their respective Gross Domestic Products (Y), and inversely proportional to the distance between them (D), which is considered as a proxy for trade costs. In a panel data framework including the time dimension the traditional model is specified as,

$$
T_{i j t}=\gamma_{0} \frac{Y_{i t} Y_{j t}}{D_{i j}}
$$

Anderson and van Wincoop (2003) recommend estimating a theoretically based gravity model accounting for 'multilateral trade resistance'. Economic theory leads to an 
expenditure share sometimes named structural gravity, which is derived from well justified theoretical foundations,

$$
T_{i j t}=\frac{Y_{i t} Y_{j t}}{Y_{t}}\left(\frac{D_{i j}}{\theta_{i t} \pi_{j t}}\right)^{1-\sigma}
$$

where $\sigma$ denotes the constant elasticity of substitution between varieties $(\sigma>1)$ and $\theta_{i t}, \pi_{j t}$ represent multilateral resistance terms that act as time-varying common exporter and importer country shifters. One way to control for these terms empirically is to add timevarying, directional, country-specific dummies to the model specification, because bilateral trade flows depend on bilateral trade costs relative to multilateral trade costs.

This model has been augmented with other variables that may potentially affect trade between countries. More specifically, common language, colonial ties, common border and trade agreements are used as proxies for familiarity, information and reduction in artificial trade barriers. Typically, the gravity equation is specified in logarithmic linear form and is estimated using cross-section or panel data. According to the most recent literature, the use of panel data is highly recommended to control for the unobserved heterogeneity of various sources, the endogeneity of the FTAs and for multilateral resistance factors.

An important issue is that trade policy is not strictly exogenous and consequently any analyses of the effects of free trade agreements using the gravity equation can suffer from endogeneity bias, as pointed out by Baier and Bergstrand (2007). These authors recommend the use of panel data regression techniques and the inclusion of bilateral fixed effects (dyadic fixed effects) to capture unobservable time-invariant bilateral factors that can affect trade flows. They also include exporter-and-time and importer-and-time fixed effects to capture unobservable time-varying 'multilateral price/resistance' terms of the exporter and importer countries.

The model that corrects for endogeneity bias and controls for multilateral resistance is given by,

$$
\ln T_{i j t=} \beta_{0}+\beta_{1} F T A_{i j t}+\delta_{i j}+\theta_{i t}+\pi_{j t}+\mu_{i j t}
$$

where $\delta_{\mathrm{ij}}$ denotes dyadic fixed effects, specified as dummy variables for each bilateral relationship and $\theta_{\mathrm{it}}, \pi_{\mathrm{jt}}$ are exporter-and-time and importer-and-time fixed effects. The inclusion of these fixed effects implies that we are not able to identify income and distance 


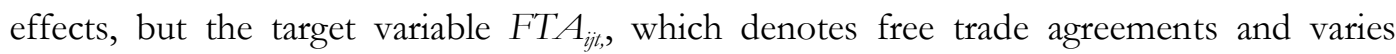
bilaterally and over time will be correctly identified.

\section{Empirical application}

Data description

We use bilateral exports and imports from 10 MENA countries ${ }^{9}$ to 61 destinations (see Table A.2 in the Appendix), which represent around 90\% of their total trade, bilateral imports have been computed in CIF prices and bilateral exports in FOB prices, both in thousands USA dollars. Exports and imports are from the COMTRADE database for the period 1994-2010 ${ }^{10}$ using the Standard International Trade Classification (SITC), Revision 3. We use sectoral data to estimate the impact of FTAs on agricultural and industrial trade flows separately. In order to obtain agricultural trade flows we took the 'food' standard definition from COMTRADE that considers the sum of sections $0,1,22$ and 4 from the SITC revision 3 classification as total agricultural trade flows and for industrial trade we use the standard definition of 'manufactures' from COMTRADE that considers the sum of sections 5,60,61,62,63,64,65,66,67,69,7 and 8 from the SITC revision 3 classification. Table 1 presents summary statistics for the variables used.

\section{(Insert Table 1)}

As regards FTAs, we consider all FTAs that entered into force for the ten MENA countries during the period and one customs union (Turkey-EU). Among them there are 5 North-South agreements: EUROMED, EFTAMED, USAMED, Israel-Canada; TurkeyEU customs union and 5 South-South: AGADIR, GAFTA, Turkey-MED, JordanSingapore and Israel-Mexico. The data on FTAs are obtained from the World Trade Organization database (See Table A.1 in the Appendix).

\section{Model specification}

The preferred model is a logarithmic version based on Anderson and van Wincoop (2003) proposed by Baier and Bergstrand (2007). We consider a model specification that accounts for both unobservable heterogeneity (time-invariant bilateral) and multilateral resistance, namely importer-and-time and exporter-and-time dummies as proposed by Baier and

\footnotetext{
9 Algeria, Egypt, Israel, Jordan, Lebanon, Libya, Morocco, Syria, Tunisia and Turkey.

${ }^{10}$ The period has been chosen taking into account the entry into force of the agreements and avoiding having a lot of zeros choosing years before 1994 .
} 
Bergstrand (2007). In this way we are able to control for all time-variant importer $\left(\boldsymbol{\delta}_{\mathrm{it}}\right)$ and exporter $\left(\psi_{\mathrm{j} t}\right)$ characteristics and for all bilateral time-invariant factors $\left(\eta_{\mathrm{ij}}\right)$ that affect bilateral trade between countries. The model specification is given by,

$$
\begin{gathered}
\operatorname{lnT}_{i j t}=\beta_{0}+\beta_{1} \text { EUROMED }_{i j t}+\beta_{2} \text { EFTAMED }_{i j t}+\beta_{3} \text { USAMED }_{i j t}+\beta_{4} \text { TURMED }_{i j t}+\beta_{5} \text { GAFTA }_{i j t}+ \\
\beta_{6} \text { AGADIR }_{i j t}+\beta_{7} \text { TUREU }_{i j t}+\beta_{8} \text { ISRCAN }_{i j t}+\beta_{9} \text { ISRMEX }_{i j t}+\beta_{10} J O R S G P_{i j t}+\delta_{i j}+\theta_{i t}+\pi_{j t}+\mu_{i j t}
\end{gathered}
$$

where $T_{i j t}$ denotes exports (imports) of manufactured and agricultural products alternatively from country $i$ to country $j$ in year $t$. The variables EUROMED ${ }_{\mathrm{i} j \mathrm{t}, \mathrm{E}}$, EFTAMED ${ }_{\mathrm{i}, \mathrm{t}, \mathrm{t}}$

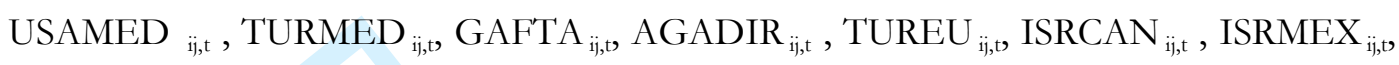
and JORSGP $\mathrm{i}_{\mathrm{i}, \mathrm{t}}$ are FTA dummy variables which take a value of 1 when the importer $i$ and exporter $j$ are both members of the agreement, starting the year in which it came into force. $\delta_{i j}$ is a country-pair fixed effect and $\theta_{i t}$ and $\pi_{j t}$ are importer-and-time and exporter-and-time fixed effects ${ }^{11} \cdot \mu_{i j t}$ is the error term that is assumed to be iid. The second and third specifications introduce the first and second lags of the FTA variable to take into account possible delayed effects of the agreements.

The next section presents the results of the estimation and discusses the effect that each agreement has had on bilateral trade flows for MENA countries.

\section{Main results}

The main results are displayed in Tables 2 and 3 for manufactured and agricultural imports and exports, respectively ${ }^{12}$, where the first column show results from the first specification, and the rest of columns show results from the second, third and last specification. Both tables present the average treatment effect (ATE) where ATE is the sum of all statistically significant coefficient estimates of each FTA. Results for GAFTA and AGADIR are only estimated using import values because after comparing the export and import values reported by MENA countries we found greater differences between the value of imports at CIF prices and exports valued at FOB prices, imports sometimes recording values that were 300 or $500 \%$ higher than export values. These differences cannot be explained by costs, insurance and freight alone, but rather are measurement errors. Therefore, to analyse the effect of intra-Arab agreements in which all the countries reported are also partners, we only use the value of imports among member countries of these agreements. When

\footnotetext{
11 See Table A.3 in the Appendix for data description.

12 The model is estimated using dyadic fixed effects after rejecting the null hypothesis of the Hausman test (orthogonality between the regressors and the bilateral unobserved heterogeneity). A complete set of results is available on request from the authors.
} 
discussing the results of a specific FTA, MENA countries or MENA region refers to all MENA countries that are members of the agreement in question, but not all MENA countries included in the study.

\section{(Insert Table 2)}

Starting by discussion the effects of North-South agreements, the estimates in Table 2 indicate that the Euromed FTA has a positive and significant impact on MENA imports from EU countries and negative and significant effect for MENA exports to the EU. Both results are in accordance to those in Cieslik and Hagemejer (2009), who obtained that the FTA decreases MENA manufactured exports to Europe by $19 \%$ (28\% in our estimations) and increases MENA imports from Europe by $41 \%\left(32.6 \%\right.$ in our results) ${ }^{13}$. When we add lagged variables to capture the delayed effect of the FTA, we observe that the average treatment effect remains very similar to the coefficients without lagged variables. Indeed, the lagged variables are not statistically significant in the case of imports.

(Insert Table 3)

When we test for strict exogeneity by adding forward FTA values, it is found that changes in EUMED $_{\mathrm{i}, \mathrm{t}+1}$ are correlated with actual trade. We consider that it is the expected outcome because despite the absence of trade liberalisation for European exports to the MENA countries before the Euromed FTA, Europe was already the first exporter in the region. As regards MENA industrial exports to EU markets, they had already been liberalized under previous bilateral cooperation agreements at the beginning of the 70 s, so the new trade agreement should not be reason to increase MENA industrial exports to the EU. The negative and statistically significant impact that we obtain of the FTA on MENA exports to European markets (left part of Table 2) could be due to the increase in European manufactured imports, specially of machinery and equipment, to local markets after the liberalisation of European imports, and to the stronger competition faced by MENA exporting firms, in particular by dual firms that are mainly selling to the domestic market and have to close down because its sales abroad did not represent an important part of its activities. In this context, some local firms are no longer productive and tend to disappear. This effect is magnified when we included the lagged effect of the agreement, reflecting a higher negative effect two years after the agreement came into force, revealing an adjustment effect. Table 3 does not show any statistical effect for agricultural products,

${ }^{13}\left(\mathrm{e}^{-0.336}\right)-1=-0.285$ and $\left(\mathrm{e}^{-0.282}\right)-1=0.326$ 
consistent with the fact that the FTAs under study do not contemplate trade liberalisation in agricultural goods.

For the EFTAMED agreement, we found a statistically positive impact on MENA manufactured exports. Table 2 shows that this effect appears two years after the agreement came into force. The liberalisation schedule of the agreement is similar to Euromed but with some differences, since MENA exports were duty free when the agreement for industrial products came into force, while EFTA exports were progressively liberalized. Hence, the positive effect obtained for the second lagged value of the FTA could be explained by this progressive liberalization schedule. Similar to what it was found for the Euromed agreement, Table 3 does not show any statistical-significant effect for agricultural products concerning the EFTAMED agreement, also this result is expected, since this FTA does not include elimination of tariffs in agricultural products.

The FTA concluded between the USA and Jordan and later with Morocco have a positive and significant effect on MENA exports. Similar to the effect obtained for the EFTAMED agreement, the second lagged variable of the FTA is statistically significant, meaning the effect appears two years after the FTA came into force. The USA FTA is one of the few FTAs including trade liberalisation for certain agricultural products. Indeed, results in Table 3 indicate that this agreement has been very beneficial to USA agricultural products. More specifically, the FTA has increased MENA imports from the USA by $110 \%$ and MENA exports to the USA by $55 \%{ }^{14}$. In this line, Hufbauer and Brunel (2009) show that the FTA has been very beneficial for traditional USA agricultural exports like wheat, corn and oilseeds, but also for other products linked to the FTA, such as livestock feed, dairy products, fruit and vegetables and live animals for breeding and for Morocco exports of Miscellaneous edible products and preparations; Essential oils and resinoids and perfume materials and Fish (not marine mammals), crustaceans, molluscs but trends remain very similar to those before the agreement.

As regards the agreement between Israel and Canada, tariffs on all industrial products manufactured in Canada and Israel as well as on a limited number of agricultural and fisheries products were eliminated when it came into force. The results show that the FTA increased manufactured Israeli exports to Canada by around $23 \%{ }^{15}$ and Israeli imports by around $64 \%$.

$14\left(\mathrm{e}^{0.743}\right)-1=0.110$ and $\left(\mathrm{e}^{0.439}\right)-1=0.551$

$15\left(\mathrm{e}^{0.203}\right)-1=0.644$ and $\left(\mathrm{e}^{0.320}\right)-1=0.377$ 
Concerning the effects of South-South agreements, in relation to the effect of the FTA between some MENA countries and Turkey, the results in Table 2 for manufactured products show that it has a positive and significant impact on imports from Turkey and a positive but not significant effect on manufactured MENA exports. Customs duties for MENA industrial products were abolished in Turkey with the entry into force of the agreement, but results do not show that the increase in MENA exports in Turkey is caused by the agreement. Differently, results in Table 3 show that MENA agricultural exports to Turkey countries increased by around $89 \%$ when the agreement came into force.

Regarding the effect of intra-Arab integration, the GAFTA FTA involves trade liberalisation for all products, including agricultural goods. As observed in Table 2 the estimated coefficient of the second lag is positive and statistically significant indicating that an impact occurs two years after the agreement came into force, reflecting the phased in effect of liberalisation. This result is similar to that obtained by Abedini and Peridy (2008). Concerning agricultural products, we also find that the FTA has a positive impact on agricultural trade (as shown in Table 3). In relation to the Agadir agreement, the results do not show any impact on manufactured or agricultural imports, for this reason results are not included on the ATE row.

The Israel-Mexico free trade agreement included liberalisation for industrial and agricultural products too. The findings in Tables 2 and 3show that the FTA concluded between both countries increased Mexican manufactured and agricultural exports and negatively affected Israeli manufactured exports, but had a positive impact on agricultural exports the year after the agreement came into force.

Finally, the agreement between Jordan and Singapore also includes trade liberalisation for manufactured and agricultural products. In our analysis we found that the agreement decreased MENA manufactured imports from Singapore, but increased agricultural imports. In addition, the FTA has a positive and significant impact on Jordan manufactured exports, but negatively affects agricultural exports. After analysing the list of agricultural products imported by MENA and comparing it to the agricultural products included in the agreement, we found that this increase is due to the reduction in tariffs on agricultural preparations, cereals, spices and palm oil, all of which are included in the FTA. In 2002, the government adopted a "National Strategy for Agricultural Development 20022010, where subsidies have been totally lifted and national agricultural products have had to compete with imported goods in the domestic and export markets. These developments 
coincided with a decline in the quality and quantity of water available for irrigation, which affected crop productivity and quality of produce and its competitiveness, in quality and price, in domestic and export markets.

Table 4 presents a summary of the results found for North-South and South-South agreements, distinguishing between agricultural and manufactured goods and specifying the agreements that include trade liberalization in agricultural goods.

(Insert Table 4)

The main conclusion is that most North-South FTAs have resulted in increased exports of MENA manufactured products, with the only exception of EUMED, whereas the effect on agricultural exports is also positive and significant but only for the agreements including trade liberalization in agricultural goods (US agreements). For South-South agreements the results are mixed, with some agreements resulting in increasing exports of manufactured goods (GAFTA, Jordan-Singapore and Israel-Canada) and some other showing no-effects (TURMED) or negative effects on MENA exports (Israel-Mexico). Meanwhile, those including tariff elimination in agricultural products have resulted in an increase in trade in those products (TURMED, GAFTA and Israel-Mexico), with the only exception of the Israel-Canada agreement, for which results are mixed. Finally, the custom union established between the UE and Turkey in 1996 show a positive impact for European exports to Turkey.

\section{Conclusions}

This paper investigates the impact of FTAs on trade flows for ten MENA countries during the period 1994-2010. We use an augmented gravity model which we estimate using up-todate panel data techniques that allow us to control for all the factors that influence bilateral trade and which are time-invariant (unobserved heterogeneity), as well as for the so-called multilateral resistance terms. We undertake the analysis distinguish between industrial products and trade in agricultural products.

The results presented show that although North-South-FTA and South-South-FTA have a differential impact on trade in MENA countries, with the former showing more positive effects on MENA's trade than the latter, both types of agreements tend to favour global market integration. Agreements between developed and developing countries include a higher number of WTO provisions, compared with North-North and South-South agreements. Concerning South-South agreements, This pattern might reflect the fact that 
developed countries sign agreements with developing countries, which usually have higher barriers to trade, to obtain a deeper level of commitments. In exchange, through a PTA, developing countries secure their access to larger markets (Orefice and Rocha, 2014). We found in general that FTAs that include agricultural products, in which these countries have the greatest comparative advantage and could help to restructure their trade balance, are more desirable for MENA countries than those that only include industrial products. Therefore, MENA countries have to give special attention to the inclusion of agricultural goods when negotiating future agreements. Efforts towards establishing better integration among Arab countries show satisfactory progress. The Great Arab Common Market (GAFTA) in particular has been fruitful to help to increase bilateral trade between Arab countries, while we do not find the same effect in the case of the Agadir agreement, perhaps because it has been implemented only recently and data limitations do not allow us for a consistent evaluation. This turn towards greater Arab integration represents new opportunities for Arab countries to promote dialogue between them and to establish new economic opportunities in the region.

In the case of Euromed integration the results show that the FTA promotes EU exports to MENA countries, but does not have a positive impact on MENA exports to the EU. Despite this fact, Europe is still the most important trading partner of some MENA countries and a reduction in the trade imbalance between the two regions is desirable. While settlement negotiations do not include trade liberalisation in agricultural products, where MENA countries are more competitive, MENA countries need to adjust their industrial policy to be able to profit from tariff reductions in intermediate inputs and in turn to increase their productivity and be more competitive in international markets.

In this context, new partners for MENA countries have emerged as important players in the Mediterranean relationship context, like Turkey, for which an increase in manufactured exports to the MENA region is observed after the FTA was signed. The FTAs signed with the USA (Morocco and Jordan) also promote industrial and agricultural exports to the USA and increase agricultural imports of MENA countries, especially wheat. The results show in general that the inclusion of agricultural products in the liberalisation schedule is more favourable for MENA countries than only including industrial products, as in the case of Euromed or the FTA signed with Turkey. 


\section{Acknowledgments}

The authors would like to thank the financial support obtained from the Universitat Jaume I, P1.1B2013-06, PREDOC/2009/55 and E-2012-09.

\section{References}

Abdelmalki, L. (2011). Émergence et intégration commerciale. Revue d'économie industrielle, 135, 9-46.

Abedini, J. and Peridy, N. (2008). The greater arab free trade area (GAFTA): an estimation of the trade effects. Journal Economic Integration, 23, 848-72.

Anderson, J. and Wincoop, E. (2003). Gravity with Gravitas: A Solution to the Border Puzzle. American Economic Review, 93, 170-19.

Awad, T. (2011). Jordan Strategy of Trade Liberalisation and the Jordanian-Turkish FTA. Working Paper No. 01/2011. University of Applied Sciences (HTW-Berlin) Web journal, Berlin.

Balcer, A. (2013). The EU and Turkey in the Southern Neighbourhood: A New Opening. Notre Europe-Jacques Delors Institute Policy Papers, 72.

Baier, S. and Bergstrand, J. (2007). Do free trade agreements actually increase members International trade?. Journal of International Economics, 71, 72-95.

Bergstrand, J., Sunesen, E. and Thelle, M. (2011). Ex post Assessment of six EU Free Trade Agreements, An econometric assessment of their impact in trade. DG Trade, European Commison, Brussels.

Broude, T. (2009). Regional Economic Integration in the Middle East and North Africa: A Primer. In European Yearbook of international Economics Law, Vol.1, (Eds) Herrmann, C and Terhechte, J.P, SpringerVerlag, Berlin, pp. 269-296.

Cieslik, A. and Hagemejer, J. (2009). Assessing the Impact of the EU $\square$ sponsored Trade Liberalisation in the MENA Countries. Journal of Economic Integration, 24, 343-368.

FEMISE (2005). Integration and Enlargement of the European Union: Lesson for the Arab Region. European Commission (FEMISE network, programme $n^{\circ}$ FEM22-07).

FEMISE (2006). An Evaluation of the Benefits and the Challenges of the South-South Integration among the Mediterranean Partners Countries. European Commission (FEMISE network, programme $n^{\circ}$ FEM22-27).

FEMISE (2008). The Greater Arab Free Trade Area: An ex-post appraisal within an imperfect competition framework. European Commission (FEMISE network, programme $n^{\circ}$ FEM32-03).

FEMISE (2009). Regional Integration, Firms' Location and Convergence: An Application to the Euro-Mediterranean Area, European Commission (FEMISE network, programme n. 3301).

FEMISE (2011). Rapport du Femise sur le partenariat euroméditerranéen 2011: Les pays mediterraneens au seuil d'une transition fondamentale. European Commission (FEMISE network). 
Hufbauer, G. and Brunel, C. (2009). Capitalizing on the Morocco-US Free Trade Agreement: A Road Map for Success. Peterson Institute for International Economics; Policy Analysis 88 edition, Washington. USA

Kepaptsoglou, K., Karlaftis, M. and Tsamboulas, D. (2010). The gravity model specification for modeling international trade flows and free trade agreement effects: A 10year review of empirical studies. The Open Economics Journal, 3, 1-13.

Montalbano, P. and Nenci, S. (2014). Assessing the trade impact of the European Neighbourhood Policy on the EU-MED Free Trade Area. Applied Economics, 46, 730-740.

Montanari, M. (2007). The Barcelona Process and the Political Economy of EuroMediterranean Trade Integration. JCMS: Journal of Common Market Studies, 45, 1011-1040.

Nugent, J. and Abdel-Latif, A. (2010). A quiz on the net benefits of trade creation and trade diversion in the QIZs of Jordan and Egypt. Economic Research Forum Working Papers, No. 514.

Orefice, G. and Rocha, N. (2014). Deep integration and production networks: an empirical analysis. The World Economy, 37, 106-136.

Peridy, N. (2005a). The trade effects of the Euro-Mediterranean partnership: What are the lessons for the ASEAN countries?. Journal of Asian Economics, 16, 125-139.

Peridy, N. (2005b). Toward a Pan-Arab free trade area: assessing trade potentialeffects of the Agadir agreement. Developing Economies, 43, 329- 345.

Romagnoli, A., and Mengoni, L. (2009). The challenge of economic integration in the MENA region: from GAFTA and EU-MFTA to small scale Arab Unions. Economic change and restructuring, 42, 69-83.

Rosen, H. (2004). Free trade agreements as foreign policy tools: The US-Israel and USJordan FTAs. In: J.Schott (ed.) Free trade agreements: US strategies and priorities, Peterson Institute, 51-78.

Ruebner, J. (2000). U.S.-Jordan Free Trade Agreement. Report RL30652, Congressional Research Service, Library of Congress, Washington.

Ruiz, J.M. and Vilarrubia, J.M. (2007). The Wise Use of Dummies in Gravity Models: Export Potentials in the Euro-MedEuro-Med Region. Bank of Spain Working Paper, No. 0720 .

Wippel, S. (2005). The Agadir Agreement and Open Regionalism. EuroMeSCo Paper No. 45, EuroMeSCo Secretariat, Lisbon.

Zarrouk J. (2000). The Greater Arab Free Trade Area: Limits and Possibilities. In Catching up with the competition: Trade opportunities and challenges for Arab countries. (Eds) B. Hoekman and J.Zarrouk, University of Michigan Press, Michigan, pp. 285-305.

Zorob, A. (2008). Intraregional Economic Integration: The Cases of GAFTA and MAFTA. In Beyond Regionalism? Regional Cooperation, Regionalism and Regionalisation in the Middle East, (Eds) C.Harders and M. Legrenzi, Aldershot and Burlington: Ashgate, London, pp. 169-183. 
Table 1. Summary statistics

\begin{tabular}{|c|c|c|c|c|c|}
\hline Variable & Obs. & Mean & SD & Min. & Max. \\
\hline \multicolumn{6}{|l|}{ TRADE: } \\
\hline Total & 20400 & 245662.9 & 912233.0 & 0 & $2.23 e+07$ \\
\hline Manufactures & 20400 & 195574.6 & 794462.5 & 0 & $2.14 \mathrm{e}+07$ \\
\hline Agriculture & 20400 & 25780.94 & 86372.5 & 0 & 2069366 \\
\hline
\end{tabular}


Table 2. Average treatment effect (ATE) of FTAs for manufactured products

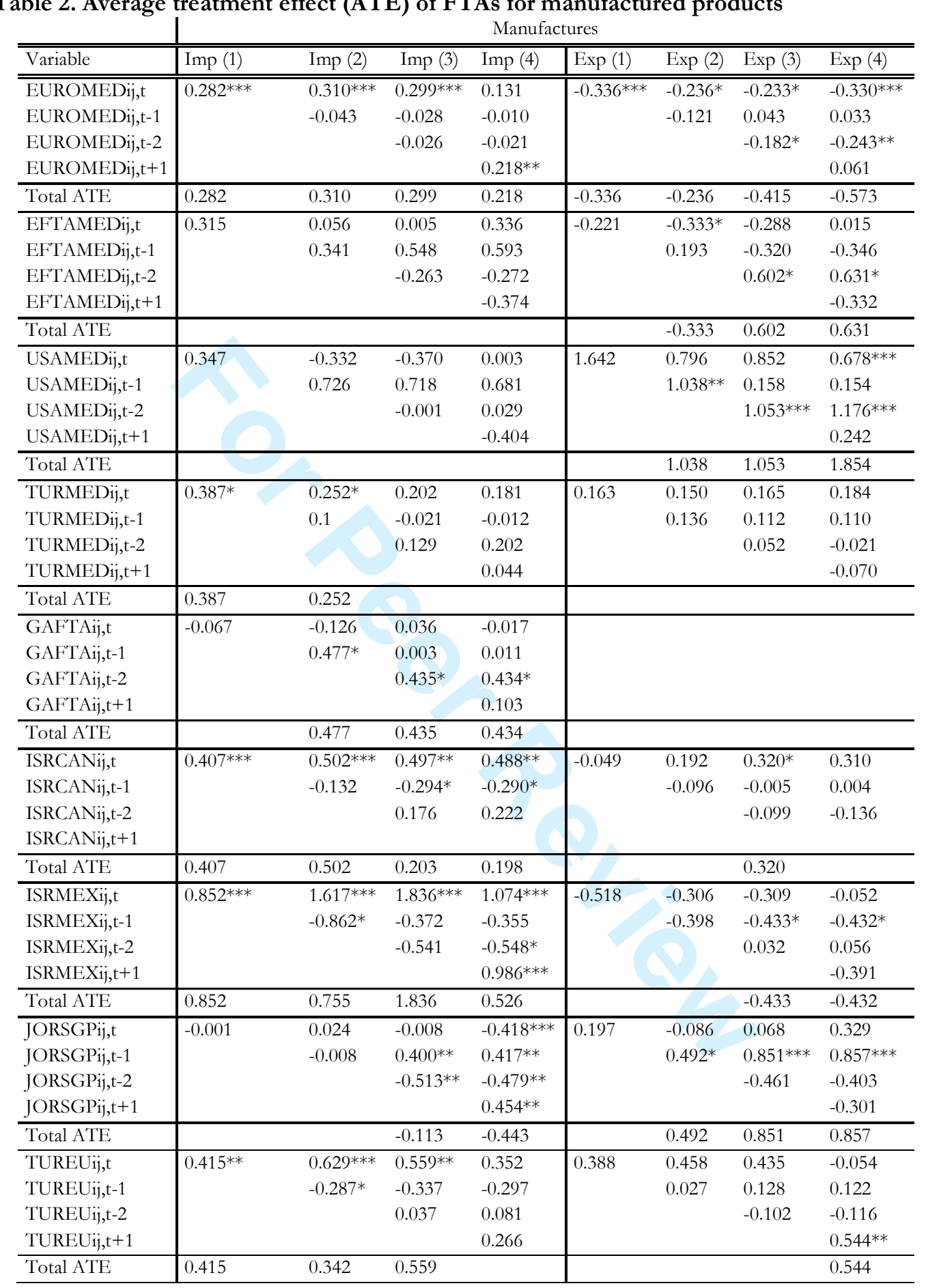

*ATE is the sum of all statistically significant estimates of each FTA. 'ns' means that coefficients are not significant. (1) are regressions with only FTA $(\mathrm{t})$, (2) are regressions with FTA(t) and FTAt-1, (3) are regressions with FTA(t) FTAt-1 and FTAt-2 and (4) with FTA(t) FTAt-1 and FTAt-2 and FTA(t+1) 
Table 3. Average treatment effect (ATE) of FTAs for agricultural products

\begin{tabular}{|c|c|c|c|c|c|c|c|c|}
\hline & \multicolumn{8}{|c|}{ Agricultural Trade } \\
\hline Variable & $\operatorname{Imp}(1)$ & $\operatorname{Imp}(2)$ & $\operatorname{Imp}(3)$ & Imp (4) & $\overline{E \operatorname{Exp}(1)}$ & Exp (2) & $\operatorname{Exp}(3)$ & $\operatorname{Exp}(4)$ \\
\hline $\begin{array}{l}\text { EUROMEDij,t } \\
\text { EUROMEDij,t-1 } \\
\text { EUROMEDij,t-2 } \\
\text { EUROMEDij,t+1 }\end{array}$ & -0.184 & $\begin{array}{l}-0.267 * * \\
0.081\end{array}$ & $\begin{array}{l}-0.250^{*} \\
0.108 \\
-0.042\end{array}$ & $\begin{array}{l}-0.373^{* * *} \\
0.121 \\
-0.010 \\
0.170\end{array}$ & 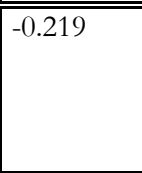 & $\begin{array}{l}-0.141 \\
-0.050\end{array}$ & $\begin{array}{l}-0.171 \\
0.078 \\
-0.173\end{array}$ & $\begin{array}{l}-0.130 \\
0.065 \\
-0.123 \\
-0.023\end{array}$ \\
\hline Total ATE & & -0.267 & -0.250 & -0.373 & & & & \\
\hline $\begin{array}{l}\text { EFTAMEDij,t } \\
\text { EFTAMEDij,t-1 } \\
\text { EFTAMEDij,t-2 } \\
\text { EFTAMEDij,t+1 }\end{array}$ & 0.330 & $\begin{array}{l}0.318 \\
0.016\end{array}$ & $\begin{array}{l}0.258 \\
0.221 \\
-0.281\end{array}$ & $\begin{array}{l}0.052 \\
0.283 \\
-0.315 \\
0.235\end{array}$ & -0.046 & $\begin{array}{l}-0.004 \\
-0.123\end{array}$ & $\begin{array}{l}-0.006 \\
0.086 \\
-0.239\end{array}$ & $\begin{array}{l}-0.128 \\
0.115 \\
-0.242 \\
0.125\end{array}$ \\
\hline Total ATE & & & & & & & & \\
\hline $\begin{array}{l}\text { USAMEDij,t } \\
\text { USAMEDij,t-1 } \\
\text { USAMEDij,t-2 } \\
\text { USAMEDij,t+1 }\end{array}$ & 0.338 & $\begin{array}{l}0.743^{* * *} \\
-0.422\end{array}$ & $\begin{array}{l}0.768^{* * *} \\
-0.358 \\
-0.060\end{array}$ & $\begin{array}{l}0.496^{* * *} \\
-0.373 \\
-0.156 \\
0.304 \\
\end{array}$ & 0.473 & $\begin{array}{l}0.133 \\
0.439 * *\end{array}$ & $\begin{array}{l}0.188 \\
0.223 \\
0.275\end{array}$ & $\begin{array}{l}0.361 \\
0.217 \\
0.263 \\
-0.187 \\
\end{array}$ \\
\hline Total ATE & & 0.743 & 0.768 & 0.496 & & 0.439 & & \\
\hline $\begin{array}{l}\text { TURMEDij,t } \\
\text { TURMEDij,t-1 } \\
\text { TURMEDij,t-2 } \\
\text { TURMEDij,t+1 }\end{array}$ & -0.219 & $\begin{array}{l}-0.277 \\
0.020\end{array}$ & $\begin{array}{l}-0.350^{*} \\
-0.050 \\
0.033 \\
\end{array}$ & $\begin{array}{l}-0.157 \\
-0.034 \\
0.010 \\
-0.283\end{array}$ & 0.505 & $\begin{array}{l}0.523 \\
0.024\end{array}$ & $\begin{array}{l}0.532 \\
-0.294 \\
0.501\end{array}$ & $\begin{array}{l}0.641 * \\
-0.324 \\
0.307 \\
-0.130\end{array}$ \\
\hline Total ATE & & & -0.350 & & & & & 0.641 \\
\hline $\begin{array}{l}\text { GAFTAij,t } \\
\text { GAFTAij,t-1 } \\
\text { GAFTAij,t-2 } \\
\text { GAFTAij,t+1 }\end{array}$ & $0.561^{*}$ & $\begin{array}{l}-0.233 \\
0.817 * *\end{array}$ & $\begin{array}{l}-0.193 \\
-0.088 \\
0.914^{* * *}\end{array}$ & $\begin{array}{l}-0.276 \\
-0.084 \\
0.919 * * * \\
0.115\end{array}$ & & & & \\
\hline Total ATE & 0.561 & 0.817 & 0.914 & 0.919 & & & & \\
\hline $\begin{array}{l}\text { ISRCANij,t } \\
\text { ISRCANij,t-1 } \\
\text { ISRCANij,t-2 } \\
\text { ISRCANij,t+1 }\end{array}$ & -0.347 & $\begin{array}{l}-0.967 * * * \\
1.193 * * *\end{array}$ & $\begin{array}{l}-1.780^{* * *} \\
1.268^{* * *} \\
-0.112\end{array}$ & $\begin{array}{l}-1.798^{* * *} \\
1.256 * * * \\
-0.048\end{array}$ & $-0.710^{* *}$ & $\begin{array}{l}-0.215 \\
-0.322\end{array}$ & $\begin{array}{l}-0.142 \\
-0.149 \\
-0.184\end{array}$ & $\begin{array}{l}-0.141 \\
-0.150 \\
-0.197\end{array}$ \\
\hline Total ATE & & 0.226 & -0.512 & -0.542 & -0.710 & & & \\
\hline $\begin{array}{l}\text { ISRMEXij,t } \\
\text { ISRMEXij,t-1 } \\
\text { ISRMEXij,t-2 } \\
\text { ISRMEXij,t+1 }\end{array}$ & -0.450 & $\begin{array}{l}-0.784 \\
0.714^{*}\end{array}$ & $\begin{array}{l}-0.391 \\
-0.037 \\
0.826 * *\end{array}$ & $\begin{array}{l}-1.024^{* *} \\
-0.033 \\
0.801 * * \\
0.816\end{array}$ & 0.522 & $\begin{array}{l}-0.233 \\
0.424\end{array}$ & $\begin{array}{l}-0.410^{*} \\
-0.581^{*} \\
1.121^{* * *}\end{array}$ & $\begin{array}{l}-0.417^{* *} \\
-0.615^{* *} \\
1.106^{* * *} \\
0.039\end{array}$ \\
\hline Total ATE & & 0.714 & 0.826 & -0.223 & & 28 & 0.130 & 0.074 \\
\hline $\begin{array}{l}\text { JORSGPij,t } \\
\text { JORSGPij,t-1 } \\
\text { JORSGPij,t-2 } \\
\text { JORSGPij,t+1 }\end{array}$ & $1.388^{* * *}$ & $\begin{array}{l}1.809^{* * *} \\
-0.476\end{array}$ & $\begin{array}{l}1.784^{* * *} \\
-0.370 \\
-0.147\end{array}$ & $\begin{array}{l}0.526^{*} \\
-0.358 \\
-0.152 \\
1.413^{* * *} \\
\end{array}$ & $-2.125^{* * *}$ & $\begin{array}{l}-0.559 \\
-1.845^{* *}\end{array}$ & $\begin{array}{l}-0.389 \\
-0.504 \\
-1.679 * *\end{array}$ & $\begin{array}{l}0.325 \\
-0.496 \\
-1.324^{*} \\
-0.813^{* *} \\
\end{array}$ \\
\hline Total ATE & 1.388 & 1.809 & 1.784 & 1.939 & -2.125 & -1.845 & -1.679 & -2.137 \\
\hline $\begin{array}{l}\text { TUREUij,t } \\
\text { TUREUij,t-1 } \\
\text { TUREUij,t-2 } \\
\text { TUREUij,t+1 }\end{array}$ & $0.692^{* * *}$ & $\begin{array}{l}1.220^{* * *} \\
-0.552^{*}\end{array}$ & $\begin{array}{l}1.490^{* * *} \\
-0.613\end{array}$ & $\begin{array}{l}0.822 \\
-0.682\end{array}$ & $\begin{array}{l}-0.164 \\
\end{array}$ & $\begin{array}{l}-0.081 \\
-0.068\end{array}$ & $\begin{array}{l}-0.185 \\
0.02 \\
-0.133\end{array}$ & $\begin{array}{l}-0.283 \\
0.016 \\
-0.103 \\
0.122\end{array}$ \\
\hline Total ATE & 0.692 & 0.668 & 1.490 & & & & & \\
\hline
\end{tabular}

*ATE is the sum of all statistically significant estimates of each FTA. 'ns' means that coefficients are not significant. (1) are regressions with only FTA (t), (2) are regressions with FTA(t) and FTAt-1, (3) are regressions with FTA(t) FTAt-1 and FTAt-2 and (4) with FTA(t) FTAt-1 and FTAt-2 and FTA(t+1) 
Table 4. Summary of FTA effects

\begin{tabular}{lll}
\hline FTA type & North-South & \\
\hline Sector: & Manufactured & Agricultural \\
\hline EUMED & $\mathrm{M}(+), \mathrm{X}(-)$ & $\mathrm{M}(-), \mathrm{X}(\mathrm{ns})$ \\
EFTAMED & $\mathrm{M}(\mathrm{ns}), \mathrm{X}(+)$ & $\mathrm{M}(\mathrm{ns}), \mathrm{X}(\mathrm{ns})$ \\
USA-Morocco* & $\mathrm{M}(\mathrm{ns}), \mathrm{X}(+)$ & $\mathrm{M}(+), \mathrm{X}(+)$ \\
USA-Jordan* & $\mathrm{M}(\mathrm{ns}), \mathrm{X}(+)$ & $\mathrm{M}(+), \mathrm{X}(+)$ \\
EU-Turkey & $\mathrm{M}(+), \mathrm{X}(\mathrm{ns})$ & $\mathrm{M}(+), \mathrm{X}(\mathrm{ns})$ \\
\hline FTA type & $\mathrm{South}-$ South & \\
\hline Sector: & $\mathrm{Manufactured}$ & Agricultural \\
\hline TURMED & $\mathrm{M}(+), \mathrm{X}(\mathrm{ns})$ & $\mathrm{M}(-), \mathrm{X}(+)$ \\
GAFTA* & $\mathrm{M}(+)$ & $\mathrm{M}(+)$ \\
AGADIR & $\mathrm{M}(\mathrm{ns})$ & $\mathrm{M}(\mathrm{ns})$ \\
Jordan-Singapore* & $\mathrm{M}(-), \mathrm{X}(+)$ & $\mathrm{M}(+), \mathrm{X}(-)$ \\
Israel-Mexico* & $\mathrm{M}(+), \mathrm{X}(-)$ & $\mathrm{M}(+), \mathrm{X}(+)$ \\
Israel-Canada & $\mathrm{M}(+), \mathrm{X}(+)$ & $\mathrm{M}(-), \mathrm{X}(-)$ \\
\hline Note: ${ }^{*}$ Agreements that include trade liberalization in agricultural goods.
\end{tabular}




\section{Appendix}

Table A. 1. List of FTAs and its country members

\begin{tabular}{|c|c|c|c|c|}
\hline FTA & Country (i) & $\begin{array}{l}\text { Year of entry into } \\
\text { force }(t)\end{array}$ & Full liberalisation & Country (j) \\
\hline EUMED & $\begin{array}{l}\text { Tunisia } \\
\text { Israel } \\
\text { Morocco } \\
\text { Jordan } \\
\text { Egypt } \\
\text { Algeria } \\
\text { Lebanon }\end{array}$ & $\begin{array}{l}1998 \\
2000 \\
2000 \\
2002 \\
2004 \\
2005 \\
2006\end{array}$ & $\begin{array}{l}12 \text { years after the } \\
\text { FTA came into force } \\
\text { plus } 3 \text { years of } \\
\text { derogation beyond } \\
\text { the initial transitional } \\
\text { period. } 4 \text { for Egypt }\end{array}$ & $\begin{array}{l}\text { Since 1995: Belgium, Germany, France, } \\
\text { Luxemburg, Italy, Netherlands, United Kingdom, } \\
\text { Ireland, Denmark, Greece, Spain, Portugal, } \\
\text { Austria, Sweden and Finland. (UE15) } \\
\text { Since 2004: Cyprus, Czech Republic, Estonia, } \\
\text { Hungry, Lithuania, Latvia, Malta, Poland, Slovak } \\
\text { Republic y Slovenia. (UE25) } \\
\text { Since 2007: Rumania y Bulgaria (UE27) }\end{array}$ \\
\hline EFTAMED & $\begin{array}{l}\text { Morocco } \\
\text { Jordan } \\
\text { Tunisia } \\
\text { Lebanon } \\
\text { Egypt }\end{array}$ & $\begin{array}{l}1999 \\
2002 \\
2005 \\
2007 \\
2007\end{array}$ & $\begin{array}{l}12 \text { years after the } \\
\text { came into force }\end{array}$ & Iceland, Liechtenstein, Norway and Switzerland \\
\hline USAMED $^{*}$ & $\begin{array}{l}\text { Jordan } \\
\text { Morocco }\end{array}$ & $\begin{array}{l}2001 \\
2006\end{array}$ & $\begin{array}{l}2010 \\
14 \text { years after the } \\
\text { FTA came into force } \\
\text { for Morocco and } 24 \\
\text { years for USA }\end{array}$ & United States \\
\hline TURMED & $\begin{array}{l}\text { Israel } \\
\text { Tunisia } \\
\text { Morocco } \\
\text { Egypt } \\
\text { Syria }\end{array}$ & $\begin{array}{l}1997 \\
2005 \\
2006 \\
2007 \\
2007\end{array}$ & $\begin{array}{l}2000 \\
2014 \\
2015 \\
2020 \\
2019\end{array}$ & Turkey \\
\hline GAFTA & $\begin{array}{l}\text { Egypt } \\
\text { Tunisia } \\
\text { Morocco } \\
\text { Jordan } \\
\text { Libya } \\
\text { Lebanon } \\
\text { Algeria } \\
\text { Syria }\end{array}$ & $\begin{array}{l}1998 \\
1998 \\
1998 \\
1998 \\
1998 \\
1998 \\
1998 \\
1998\end{array}$ & $\begin{array}{l}\text { Full liberalisation in } \\
2005\end{array}$ & $\begin{array}{l}\text { Bahrain, Egypt, Arab Emirates, Iraq, Libya, Jordan, } \\
\text { Kuwait, Lebanon, Morocco, Oman, Palestine, } \\
\text { Qatar, Saudi Arabia, Syria, Sudan, Tunisia, Yemen }\end{array}$ \\
\hline ISR $^{*}$ & Israel & $\begin{array}{l}1997 \\
2000\end{array}$ & $\begin{array}{l}1999 \\
2005\end{array}$ & $\begin{array}{l}\text { Canada } \\
\text { Mexico }\end{array}$ \\
\hline JORSGP & Jordan & 2005 & 2015 & Singapore \\
\hline AGADIR & $\begin{array}{l}\text { Morocco } \\
\text { Jordan } \\
\text { Egypt } \\
\text { Tunisia } \\
\end{array}$ & $\begin{array}{l}2006 \\
2006 \\
2006 \\
2006\end{array}$ & 2006 & Morocco, Jordan, Egypt, Tunisia \\
\hline TUREU & Turkey & 1996 & 1996 & EU27 \\
\hline
\end{tabular}

Note: *An FTA between Israel and USA came into force in 1985, however our period of analysis starts in 1990. Therefore, we cannot estimate the effect of this agreement. 
Table A. 2. Country list

$\begin{array}{llll}\text { Algeria } & \text { Finland } & \text { Korea, Republic } & \text { Russia } \\ \text { Argentina } & \text { France } & \text { Kuwait } & \text { Saudi Arabia } \\ \text { Australia } & \text { Germany } & \text { Latvia } & \text { Singapore } \\ \text { Austria } & \text { Greece } & \text { Lebanon } & \text { Slovakia } \\ \text { Belgium-Luxemburg } & \text { Hong Kong } & \text { Libya } & \text { Slovenia } \\ \text { Brazil } & \text { Hungary } & \text { Lithuania } & \text { Spain } \\ \text { Bulgaria } & \text { Iceland } & \text { Malta } & \text { Sweden } \\ \text { Canada } & \text { India } & \text { Mexico } & \text { Switzerland } \\ \text { Chile } & \text { Indonesia } & \text { Morocco } & \text { Syria } \\ \text { China } & \text { Iran } & \text { Netherlands } & \text { Thailand } \\ \text { Cyprus } & \text { Ireland } & \text { New Zealand } & \text { Tunisia } \\ \text { Czech Republic } & \text { Israel } & \text { Norway } & \text { Turkey } \\ \text { Denmark } & \text { Italy } & \text { Poland } & \text { Ukraine } \\ \text { Egypt } & \text { Japan } & \text { Portugal } & \text { United Arab Emirates } \\ \text { Estonia } & \text { Jordan } & \text { Romania } & \text { United Kingdom } \\ & & & \text { United States }\end{array}$


Table A. 3.Data description

\begin{tabular}{|c|c|c|c|}
\hline \multicolumn{4}{|c|}{ Dependent Variable } \\
\hline Variables & Description & Measure & Data Source \\
\hline $\begin{array}{l}\text { Imp, Exp } \\
\text { (Manufactures) }\end{array}$ & $\begin{array}{l}\text { Manufactured Imports / Exports } \\
\text { (SITC.rev3) }\end{array}$ & \multirow{3}{*}{$\begin{array}{l}\text { In thousands of } \\
\text { USA dollars }\end{array}$} & \multirow{3}{*}{$\begin{array}{l}\text { COMTRADE (United } \\
\text { Nations Commodity Trade } \\
\text { Statistics Database) }\end{array}$} \\
\hline $\begin{array}{l}\text { Imp, Exp } \\
\text { (Total) }\end{array}$ & Total imports less fuel (cod.3 SITC rev.3) & & \\
\hline $\begin{array}{l}\text { Imp, Exp } \\
\text { (Agricultural) }\end{array}$ & $\begin{array}{l}\text { Agricultural exports SITC. rev3 (Product } \\
\text { codes: } 0,1,22 \text { and } 4\end{array}$ & & \\
\hline \multicolumn{4}{|c|}{ Independent Variable } \\
\hline FTAij,t & $\begin{array}{l}\text { This variable takes a value of } 1 \text { when } \\
\text { countries } i \text { and } j \text { are both member of the } \\
\text { agreement (as describe in Table A.1) }\end{array}$ & Dummy variable & WTO (www.wto.org) \\
\hline
\end{tabular}

